\title{
ARE METALS OF ANTIFOULING PAINTS TRANSFERRED TO MARINE BIOTA?
}

\author{
Wladimir C. Paradas \& Gilberto M. Amado Filho* \\ Instituto de Pesquisas Jardim Botânico do Rio de Janeiro \\ (Rua Pacheco Leão, 915, 22460-030 Rio de Janeiro, RJ, Brazil) \\ gfilho@jbrj.gov.br.
}

\begin{abstract}
A B S T R A C T
Because of its high toxicity, TBT (trybutiltin) was banned since 2003, which resulted in a greater reuse of $\mathrm{Cu}$ as based-biocide in antifouling paints (AFP). The aim of this work is to determine if metals form of AFP are transferred to benthic organisms from Guanabara Bay (GB) (Rio de Janeiro, Brazil). Metal concentrations were measured in two main fouling algae species Ulva flexuosa and U. fasciata and one isopod species, Sphaeroma serratum, in two GB marinas areas from sites with artificial substrate covered by AFP and natural substrate. In addition, control samples were collected in an adjacent open ocean area. Concentrations of $\mathrm{Cd}, \mathrm{Cr}, \mathrm{Cu}, \mathrm{Pb}$ and $\mathrm{Zn}$ were determined by Atomic Absortion Spectrophotometry. Higher concentrations of $\mathrm{Cu}, \mathrm{Pb}$ and $\mathrm{Zn}$ were detected in both algal species from GB in relation to control areas. Among samples of algae and isopod species from GB, populations collected over artificial surfaces covered by AFP presented significantly higher metal concentration than population of rocky natural substrate. Our data showed that the leaching of metals by antifouling paints present on decks and boats are being taken up by algae and isopods. These results indicate that antifouling coatings are the main source of heavy metal to biota of GB marina area.
\end{abstract}

\section{RESUMO}

Devido sua alta toxicidade, o TBT está banido desde 2003, o que resultou na re-utilização de tintas a base de cobre. O objetivo deste trabalho é determinar se os metais provenientes das tintas antiincrustantes (AFP) são transferidos para organismos bentônicos da Baía de Guanabara (BG) (Rio de janeiro, Brasil). Concentrações de metais foram analisadas em duas espécies de algas Ulva flexuosa e $U$. fasciata e no isópoda, Sphaeroma serratum, em duas áreas de marinas em locais de substrato artificial coberto com tintas AFP e em locais de substrato natural. Também foram coletadas amostras em uma área oceânica (controle). Concentrações de $\mathrm{Cd}, \mathrm{Cr}, \mathrm{Cu}, \mathrm{Pb}$ e $\mathrm{Zn}$ foram determinadas por Espectrofotometria de Absorção Atômica. Concentrações mais elevadas de $\mathrm{Cu}, \mathrm{Pb}$ e $\mathrm{Zn}$ foram detectadas na BG em ambas espécies de algas em relação a área controle. Dentre as espécies de algas e do isópoda da BG, as populações coletadas sobre as superfícies cobertas com AFP apresentaram concentrações significativamente mais elevadas do que as populações do substrato natural. Os resultados obtidos demonstram que a liberação de metais presentes nas AFP dos decks e embarcações, estão sendo acumulados pelas algas e isópodas. Esses resultados indicam que o revestimento com AFP é a principal fonte de metais para a biota de marinas em áreas da BG.

Descriptors: Antifouling paints, $\mathrm{Cu}$, Metal accumulation, Benthic organisms, Guanabara Bay.

Descritores: Tintas anti-incrustantes, Cobre, Acumulação, Organismos bentônicos, Baía de Guanabara.

\section{INTRODUCTION}

Antifouling paints are usually applied on boat hulls, ships and small vessels to prevent the growth of fouling organisms, including bacteria, macroalgae, mussels, barnacles and invertebrates. Most of antifouling coatings are based on selfpolishment system that contains biocides, which are slowly released in the environment being toxic to

(1) Paper presented at the $1^{\text {st }}$ Brazilian Congress of Marine Biology, on 15-19 May, 2006. Rio de Janeiro, Brazil. fouling organisms (Boxall et al., 2000; Callow \& Callow, 2002). In the recent past, trybutyltin (TBT) was used as the main biocide in antifouling paints. Because of TBT-based antifouling paints present high toxicity, its use was banned since 2003 and regulations were implemented to phase out on all vessels by 2008 (IMO, 2001) resulting in a greater re-use of Cu-based antifouling paints (Warken et al., 2004).

Trace metals have been identified as important constituents contaminating sediments in marinas and harbors. Where dissolved metals in water column are measured in marinas, they frequently 
exceed levels of concern (Valkirs et al., 2003). Marina and harbor areas are inherently protected from strong water movement, thus providing calm water for navigation, but at the same time restrict water circulation. Copper is known to be high in sediments and waters of ports (Valkirs et al., 2003; Schiff et al., 2004) and marinas (e.g. Turner et al., 1997; GuerraGarcía \& García-Gómez, 2005).

A lot of studies have been developed in order to quantify and predict the metal fraction that is being leached by antifouling paints from boats to the environment. It is well documented, that higher $\mathrm{Cu}$ concentrations are found in locked marinas rather than in open water areas, and that $\mathrm{Cu}$ oxide is the most used biocide in the composition of these paints (Boxall et al., 2000; Schiff et al., 2004; Guerra-García \& GarcíaGómez, 2005). An increase in $\mathrm{Cu}$ contents in oyster populations at Arcachon Bay, were determined by Claisse \& Alzieu (1993), since the TBT use was phased-out in France. Although $\mathrm{Cu}$ is important as a micronutrient for algal growth, it is highly toxic at elevated concentrations in the ionic forms (Gledhill et al., 1997).

As result of several characteristics, Ulva species (Ulvophyceae) are widely used as biomonitors to assess metal concentration in aquatic environments. These include its sedentary and cosmopolitan nature, its abundant populations, and its high capability to accumulate $\mathrm{Cu}$ concentrations (Ho et al., 1990; Riquelme et al., 1997; Correa et al., 1999; Haritonidis \& Malea, 1999; Andrade et al., 2004). The genus Ulva can tolerate lower and medium $\mathrm{Cu}$ concentrations, showing high capacity to metal accumulation, due to mechanisms of cellular immobilization (Andrade et al., 2004).

Invertebrates are generally more sensitive to pollutants than either fish or algae. Among them, amphipods, isopods and decapods are important components of the marine intertidal and subtidal fauna (Levent et al., 1999). Isopods live among algal turfs, crevices or under the stones, are omnivorous, feeding on bacterial biofilms, algae or/and organic detritus (Levent et al., 1999). The isopod S. serratum that lives among Ulva turfs, present a large range of geographical distribution in the Atlantic Ocean and is an abundant species in marinas and harbor areas.

The aim of this work is to assess the concentrations of metals in two main fouling algal species, Ulva flexuosa and Ulva fasciata, and one isopod species Sphaeroma serratum (Sphaeromatidae) in marina areas at Guanabara Bay (Rio de Janeiro, Brazil) in order to determine the contribution of antifouling paints to metal accumulation by these organisms. In this way, samples were collected in three sites, two into the Bay and one in an open water rocky shore.

\section{Material ANd Methods}

Samples, including the two seaweeds ( $U$. flexuosa and $U$. fasciata) were collected at the intertidal zone in two sites at Guanabara Bay (GB), Marina da Gloria (MG) and Ribeira (RI) in winter (August 2004) and summer (February 2005). For comparative purpose, samples of the seaweed species were collected at Arpoador Beach (AB) (City of Rio de Janeiro, Brazil), an open ocean area. Populations of the epi-faunal isopod $S$. serratum were found only at the MG site and the individuals were hand collected. Samples were obtained in both natural (RS) and artificial substrate (DECK). Algal samples were collected using a stainless scissor in order to remove the basal portions (a mean distance of $5 \mathrm{~mm}$ from substrate surface). Samples were transported in local seawater to laboratory.

In the laboratory samples were washed in seawater, therefore washed in distilled water and dried at $\left(60^{\circ} \mathrm{C}, 48 \mathrm{~h}\right)$. Samples were weighed and approximately $250 \mathrm{mg}$ (triplicates) of each sample were ashed $\left(450^{\circ} \mathrm{C}, 48 \mathrm{~h}\right)$ and digested in $10 \mathrm{ml} \mathrm{HNO}_{3}$ (Merck PA 65\%). After evaporation the residue was re-dissolved in $0.1 \mathrm{~N} \mathrm{HCl}(15 \mathrm{ml})$ and stored in polyethylene bottles until analyses. Five trace metals were measured $\mathrm{Cd}, \mathrm{Cu}, \mathrm{Cr}, \mathrm{Pb}$ and $\mathrm{Zn}$ by flame atomic absorption spectrophotometry (AAS-Varian AA-147). The results were expressed in $\mu \mathrm{g} \cdot \mathrm{g}^{-1}$ of dry weight. One common Brazilian antifouling paint (AFP) (RENNER AF 10) used on commercial and military vessels was submitted to analyses (for $\mathrm{Cd}, \mathrm{Cr}, \mathrm{Cu}, \mathrm{Pb}$ and $\mathrm{Zn}$ ), in this case, samples weighed approximately $100 \mathrm{mg}$ (triplicates). Analytical procedures were tested by comparative analyses of International Atomic Energy Agency (IAEA) certified reference material IAEA-140 (sea plant homogenate, Fucus). One-Way Analysis of Variance (ANOVA) was used to compare metal concentrations among sampling sites and natural and artificial substrate. Differences were considered significant when $\mathrm{p}<0.05$ (STATISCA 4.2).

\section{RESULTS}

Among the five analyzed metals, concentrations of $\mathrm{Cu}, \mathrm{Pb}$ and $\mathrm{Zn}$ were significantly higher in algae from the GB sites than $A B$ ones $(n=$ $60, \mathrm{p}<0.05)$. The $\mathrm{Cu}$ concentration in GB seaweed samples varied between $16.95 \pm 7.78 \mu \mathrm{g} . \mathrm{g}^{-1}$ and $152.32 \pm 16.32 \mu \mathrm{g} . \mathrm{g}^{-1}$; the highest value $(152.32 \pm$ $\left.16.07 \mu \mathrm{g} . \mathrm{g}^{-1}\right)$ was observed in $U$. flexuosa samples of MG DECK (twenty-seven times higher than the value of $\left.\mathrm{AB}, 5.34 \pm 1.74 \mu \mathrm{g} \cdot \mathrm{g}^{-1}\right)$ and $\mathrm{MG}$ DECK concentration is still significantly higher $(\mathrm{n}=9, \mathrm{p}<$ 0.05 ) than concentration observed in $U$. flexuosa populations from the two other GB sampled sites (MG 
RS samples $=19.41 \pm 1.47 \mu \mathrm{g} \cdot \mathrm{g}^{-1}$ and RI RS samples $\left.=18.30 \pm 3.40 \mu \mathrm{g} \cdot \mathrm{g}^{-1}\right)$.

Levels of $\mathrm{Pb}$ in seaweeds from GB samples varied between $8.04 \pm 1.75 \mu \mathrm{g} . \mathrm{g}^{-1}$ and $27.68 \pm 8.05$ $\mu \mathrm{g} . \mathrm{g}^{-1}$; the highest value was found in $U$. flexuosa samples from MG DECK (six times higher than the value of $\left.\mathrm{AB}, 4.60 \pm 0.50 \mu \mathrm{g} \cdot \mathrm{g}^{-1}\right)$. In the same way of the $\mathrm{Cu}$ results, $U$. flexuosa $\mathrm{MG}$ DECK $\mathrm{Pb}$ concentration was significantly higher $(n=9 p<0.05)$ than that of samples from the two other GB sites (MG RS, $16.60 \pm 3.3$ and RI RS, $\left.15.40 \pm 3.25 \mu \mathrm{g} . \mathrm{g}^{-1}\right)$. At MG RS, U. flexuosa samples showed significantly (n $=6, \mathrm{p}<0.05)$ higher $\mathrm{Pb}$ concentration than $U$. fasciata (Table 1).

Levels of $\mathrm{Zn}$ varied between $27.44+1.67$ $\mu \mathrm{g} . \mathrm{g}^{-1}$ to $174.37 \pm 32.79 \mu \mathrm{g} \cdot \mathrm{g}^{-1}$ in GB samples; the highest concentration was observed in $U$. flexuosa
(MG DECK) and it was seven times higher than in AB samples $\left(24.76 \pm 4.79 \mu \mathrm{g}^{-g^{-1}}\right)$ and yet, it was significantly higher $(\mathrm{n}=9 \mathrm{p}<0.05)$ than the concentration in the two other GB populations (MG $\mathrm{RS}, 68.88 \pm 0.01 \mu \mathrm{g} \cdot \mathrm{g}^{-1}$ and RI RS, $26.47 \pm 1.42$ $\left.\mu \mathrm{g} . \mathrm{g}^{1}\right)$.

Concentration of $\mathrm{Cd}$ and $\mathrm{Cr}$ in seaweeds samples from GB are in the same range of that observed in samples from the open water collecting site (Table 2). No difference in metal concentration was found between organisms collected in the two distinct seasons (Table 1). Comparing the mean concentration of $\mathrm{Cu}, \mathrm{Pb}$ and $\mathrm{Zn}$ in algal population from MG DECK it was observed that $U$. flexuosa presented significantly higher $\mathrm{Cu}$ and $\mathrm{Zn}$ concentration $(\mathrm{n}=18, \mathrm{p}<0.05)$ than $U$. fasciata samples (Fig. 1).

Table 1. Copper, lead and zinc concentrations ( $\mu \mathrm{g} \cdot \mathrm{g}^{-1}$ dry weight) in the three species (Ulva flexuosa, U. fasciata and Sphaeroma serratum) at the sampled sites of Guanabara Bay (MG DECK= Marina da Glória deck; MG RS= Marina da Glória rocky shore; RI RS= Ribeira rocky shore) and at the control area (Arpoador beach). Mean values and standard deviation (in italic).

\begin{tabular}{|c|c|c|c|c|c|c|}
\hline \multirow[t]{2}{*}{$\begin{array}{c}\text { Species/ } \\
\text { Samples sites }\end{array}$} & \multicolumn{2}{|c|}{$\mathbf{C u}$} & \multicolumn{2}{|c|}{$\begin{array}{c}\text { Metals/Seasons } \\
\mathbf{P b}\end{array}$} & \multicolumn{2}{|c|}{$\mathbf{Z n}$} \\
\hline & summer & winter & summer & winter & summer & winter \\
\hline \multicolumn{7}{|l|}{ U. flexuosa } \\
\hline \multirow[t]{2}{*}{ MG DECK } & 144.26 & 152.32 & 27.68 & 27.40 & 174.37 & 172.42 \\
\hline & 15.21 & 16.07 & 8.05 & 7.5 & 32.79 & 31.47 \\
\hline \multirow[t]{2}{*}{ MG RS } & 19.41 & 19.39 & 15.99 & 16.60 & 42.54 & 68.88 \\
\hline & 1.47 & 0.86 & 2.38 & 3.3 & 5.08 & 0.01 \\
\hline \multirow[t]{2}{*}{ RI RS } & 17.25 & 18.30 & 13.33 & 15.40 & 27.44 & 26.47 \\
\hline & 2.8 & 3.4 & 3.36 & 3.25 & 1.67 & 1.42 \\
\hline \multirow[t]{2}{*}{$\mathbf{A B}$} & 5.79 & 5.40 & 4.51 & 4.60 & 24.76 & 23.40 \\
\hline & 0.80 & 0.75 & 0.48 & 0.50 & 4.79 & 4.60 \\
\hline \multicolumn{7}{|l|}{ U. fasciata } \\
\hline \multirow[t]{2}{*}{ MG DECK } & 27.83 & 26.75 & 27.01 & 27.30 & 45.62 & 44.35 \\
\hline & 3.35 & 3.34 & 8.05 & 7.5 & 3.83 & 2.08 \\
\hline \multirow[t]{2}{*}{ MG RS } & 21.09 & 13.41 & 9.02 & 9.82 & 35.5 & 34.5 \\
\hline & 1.64 & 2.8 & 1.75 & 4.45 & 0.83 & 0.90 \\
\hline \multirow[t]{2}{*}{ RI RS } & 16.95 & 21.05 & 8.04 & 10.05 & 34.21 & 32.45 \\
\hline & 7.78 & 4.45 & 1.75 & 2.85 & 0,75 & 0.50 \\
\hline \multirow[t]{2}{*}{$\mathbf{A B}$} & 5.40 & 5.34 & 2.81 & 2.70 & 14.97 & 15.14 \\
\hline & 1.60 & 1.74 & 0.45 & 0.42 & 5.54 & 4.35 \\
\hline \multicolumn{7}{|l|}{ S.serratum } \\
\hline \multirow[t]{2}{*}{ MG DECK } & 200.29 & 199.05 & 17.05 & 18.05 & 230.00 & 225.04 \\
\hline & 4.48 & 3.3 & 0.48 & 0.55 & 11.06 & 12.45 \\
\hline \multirow[t]{2}{*}{ MG RS } & 119.95 & 120.30 & 6.66 & 6.72 & 128.28 & 122.28 \\
\hline & 7.65 & 6.8 & 0.33 & 0.35 & 13.01 & 12.01 \\
\hline
\end{tabular}


Table 2. Cadmium and chromium mean concentration $\left(\mu \mathrm{g} . \mathrm{g}^{-1}\right.$ dry weight \pm standard deviation) in three species from GB (Guanabara Bay) and AB (Arpoador Beach - Control area) sample sites. ND means below the limit of detection.

\begin{tabular}{ccc}
\hline Sites/species & \multicolumn{2}{c}{ Metals } \\
& Cd & Cr \\
\hline GB & & \\
U. flexuosa & 0.66 & 16.00 \\
U. fasciata & 0.07 & 2.85 \\
AB & 0.49 & 12.61 \\
S. serratum & 0.13 & 0.93 \\
U. flexuosa & $\mathrm{ND}$ & $\mathrm{ND}$ \\
& & \\
U. fasciata & 0.50 & 15.00 \\
& 0.05 & 2.4 \\
\hline
\end{tabular}

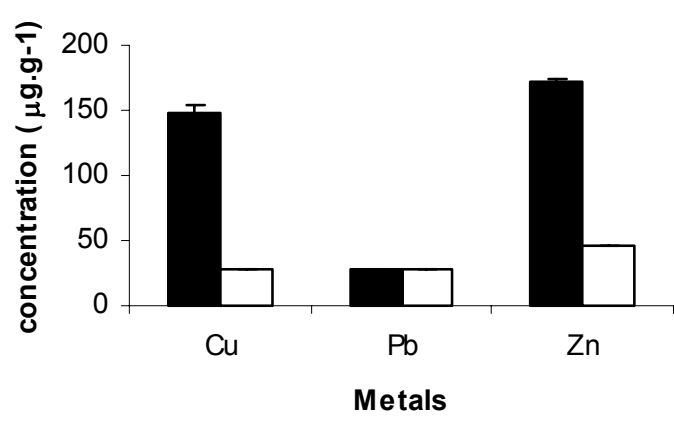

Fig. 1. Mean ( \pm standard deviation) metal concentration in U.flexuosa (black columm) and U.fasciata (white columm) from MG DECK sample site.

In relation to the isopod $S$. serratum, significantly higher concentrations of $\mathrm{Cu}, \mathrm{Pb}$ and $\mathrm{Zn}$ were observed in the population from MG DECK $(\mathrm{Cu}$ $=200.29 \pm 4.48 \mu \mathrm{g} \cdot \mathrm{g}^{-1} ; \mathrm{Pb}=18 \pm 0.55 \mu \mathrm{g} \cdot \mathrm{g}^{-1}$ and $\mathrm{Zn}=$ $\left.230 \pm 11 . \overline{0} 6 \mu \mathrm{g} \cdot \mathrm{g}^{-1}\right)$ than RS $\left(\mathrm{Cu}=120.30 \pm 6.8 \mu \mathrm{g} \cdot \mathrm{g}^{-1}\right.$; $\mathrm{Pb}=6.72 \pm 0.35 \mu \mathrm{g} \cdot \mathrm{g}^{-1}$ and $\mathrm{Zn}=128.28 \pm 13.01$ $\left.\mu \mathrm{g} . \mathrm{g}^{-1}\right)$, that means differences in concentration of 1.6 $(\mathrm{Cu}), 2.6(\mathrm{~Pb})$ and $1.8(\mathrm{Zn})$ times between MG DECK and RS. (Table 1). Concentrations of $\mathrm{Cd}$ and $\mathrm{Cr}$ in $S$. serratum were below the analytical limit of detection.

Among the five metals analyzed in the antifouling paint sample, $\mathrm{Cu}$ and $\mathrm{Zn}$ presented the highest concentrations, respectively $324,785 \pm 57,000$ $\mu \mathrm{g} . \mathrm{g}^{-1}$ and $145,232 \pm 12,401$. The following metal concentration in AFP (RENNER AF 10) samples were in order to $\mathrm{Cu}>\mathrm{Zn}>\mathrm{Pb}>\mathrm{Cr}>\mathrm{Cd}$. The results showed that $\mathrm{Cu}$ and $\mathrm{Zn}$ are the main metal elements present in this type of paint (Table 3).

Table 3. Mean metal concentration $\left(\mu \mathrm{g} \cdot \mathrm{g}^{-1}\right.$ dry weight \pm standard deviation) in antifouling paint RENNER AF10.

\begin{tabular}{cc}
\hline \hline Metals & Concentration \\
\hline $\mathrm{Cd}$ & $3.59 \pm 0.40$ \\
$\mathrm{Cr}$ & $16.84 \pm 2.59$ \\
$\mathrm{Cu}$ & $324,785 \pm 57,000$ \\
$\mathrm{~Pb}$ & $247.63 \pm 37.53$ \\
$\mathrm{Zn}$ & $145,232 \pm 12,401$ \\
\hline
\end{tabular}

\section{DisCUSSION}

Copper loading from antifouling surfaces can be a substantial portion of the total loading of $\mathrm{Cu}$ into a harbor or estuary (Valkirs et al., 2003). The rank order in terms of number of vessels treated with a particular biocide was $\mathrm{Cu}$ (I) oxide $>$ diuron $>\mathrm{Cu}$ thiocyanate $>$ Irgarol 1051 and $\mathrm{Zn}$ pyrythione (Boxall et al., 2000). Our results indicated that the main biocide present in AFP paint analyzed was $\mathrm{Cu}$. Dissolved $\mathrm{Cu}$ is the second most toxic element after mercury (Gledhill et al., 1997), and presented a profound effect on the environment, principally on the initial-stage of growth in several organisms (Andrade et al., 2004). Our results showed high amount of $\mathrm{Cu}$ and $\mathrm{Zn}$ in AFP (RENNER AF 10) formula and this observed pattern of $\mathrm{Cu}$ and $\mathrm{Zn}$ concentration is found in the majorority of AFP paints compositions (Yonerara et al., 2001; Callow \& Callow, 2002; Thouvenin et al., 2002; Valkirs et al., 2003; Löschau et al., 2005).

In the present study, heavy metal concentrations in organisms were in the following order $\mathrm{Zn}>\mathrm{Cu}>\mathrm{Pb}>\mathrm{Cr}>\mathrm{Cd}$. Cadmium and chromium in seaweeds presented the same metal levels found in non-contaminated waters (Amado Filho et al., 1999). Our data showed higher $\mathrm{Cu}, \mathrm{Pb}$ and $\mathrm{Zn}$ concentrations in algae populations from GB sites than AB. Comparisons among the present data with previous studies of metal concentration in GB far from marina areas (Carvalho et al., 1992; Karez et al., 1994) showed that samples collected in marina sites 
(present study) were higher for $\mathrm{Cu}, \mathrm{Pb}$ and $\mathrm{Zn}$. Marina areas are generally protected against strong water movement, which restricts the water circulation and contributing to the metal bioavailability (Valkirs et al., 2003). Although differences between GB and control area were seen, Moore \& Ramamurti (1987) considered that in general $\mathrm{Zn}$ levels in benthic algae from non-polluted areas do not exceed $100 \mu \mathrm{g} . \mathrm{g}^{-1}$. Only in MG DECK $\mathrm{Zn}$ levels exceeded the background level of $100 \mu \mathrm{g} \cdot \mathrm{g}^{-1}$, suggesting that antifouling paints are the main source of $\mathrm{Zn}$ to marina and yacht club areas. Copper based antifouling paints regularly contain $\mathrm{Zn}$ (as $\mathrm{ZnO}$ ) that is normally used as booster biocide for $\mathrm{Cu}$, increasing the toxicity of $\mathrm{Cu}$ by 200 times (Waterman et al., 2005). Algae populations from MG DECK (which were located just a few meters from RS site), presented higher $\mathrm{Cu}$ concentration than RS and RI populations, indicating that $\mathrm{Cu}$ present in antifouling paints are being transferred to these populations. Ambient concentrations of dissolved $\left(\mathrm{Cu}^{++}\right)$in sea water are very low, averaging $4 \mathrm{nM}$ in waters with salinity over $35 \%$ (Gledhill et al., 1997). Cuprous ion $\left(\mathrm{Cu}^{+}\right)$ released from $\mathrm{Cu}$-based coatings is rapidly converted to cupric ion $\left(\mathrm{Cu}^{++}\right)$and then more slowly forms inorganic and organic complexes (Valkirs et al., 2003). In this way, the higher concentrations found in samples from MG DECK and the metal concentrations decrease along a short distance gradient between MG DECK and MG RS should be related to the proximity of the $\mathrm{Cu}$ source and availability in seawater. In the same way of $\mathrm{Cu}$ and $\mathrm{Zn}, \mathrm{Pb}$ in seaweeds samples from MG DECK was higher than RS, showing the contribution of antifouling paints as a source of $\mathrm{Pb}$.

Reed \& Moffat (1983) shown that different ecotypes of $U$. compressa presented different $\mathrm{Cu}$ tolerance (ship fouling algae presented higher metal concentration than non-fouling populations). Similar results were observed in our data, where population from surface covered by antifouling paints revealed higher metal concentration than populations from natural substrates. The higher $\mathrm{Cu}$ and $\mathrm{Zn}$ concentrations in $U$. flexuosa than $U$. fasciata confirm the capability of $U$. flexuosa to accumulate and immobilize metals (Andrade at al., 2004), which explain why this species is considered the major fouling organism commonly found adhering to boat hulls protected with antifouling paints (Callow \& Callow, 2002).

Like algal samples the isopod $S$. serratum presented higher $\mathrm{Cu}$ and $\mathrm{Zn}$ concentrations in DECK samples than in rocky shore ones, indicating that the same pattern of metal levels found in algae were seen. Populations that were located over antifouling paint surface into algal turfs showed higher metal concentration than natural substrate populations. Probably the saprophagous and omnivorous food habits of isopods species (Rupert et al., 2005) contributed to the high $\mathrm{Cu}, \mathrm{Zn}$ and $\mathrm{Pb}$ levels found in marina area. In sites where the food contains high concentrations of cooper, the isopods assimilate metals in excess of their requirements, storing the excess of $\mathrm{Cu}$ within insoluble granules associated with sulphur and calcium, in the $\mathrm{S}$ cells of the hepatopancreas (Wieser, 1967; Donadey \& Besse, 1972; Hopkin \& Martin, 1982).

Finally, our data showed that the leaching of metals by antifouling paints present on decks and boats are being taken up by algae and isopods. These results indicate that antifouling coatings are the main source of heavy metal to marina areas. The utilization of $\mathrm{Cu}$ based formulations as a substitute for TBT did not avoid the negative effect of antifouling paints released to marine ecosystems, especially benthic communities of marina and harbor surrounding areas, claiming to new biomonitoring studies in this field, concomitant with efforts of research groups around the world on the development of antifouling paints free of toxic biocides.

\section{ACKNOWLEDGMENTS}

The authors thank the director of Marina da Glória, Dr. Sérgio Ricardo M. Meirelles by the access and support for sampling into the establishment; the Captain of Material Division (Brazil Navy) Msc. Dauton L. F. Menezes for providing antifouling paints; Dr. Cristiana S. Serejo (Museu Nacional/UFRJ) and Dr. Elaine Albuquerque Figueiredo (Universidade Santa Úrsula) by the isopods identification and Ricardo Thomas for AAS measurements. This work was supported by CNPq (Edita Universal 2004, research grants to G.M. Amado Filho - Produtividade em Pesquisa/Oceanografia, and W. C. Paradas, Iniciação Científica, quota/ Oceanografia).

\section{REFERENCES}

Amado Filho, G. M.; Andrade, L. R.; Karez, C. S.; Farina, M. \& Pfeiffer, W. C. 1999. Brown algae species as biomonitors of $\mathrm{Zn}$ and $\mathrm{Cd}$ at Sepetiba Bay, Rio de Janeiro, Brazil. Mar. Environ. Res., 48:213-224.

Andrade, L. R.; Farina, M. \& Amado Filho, G. M. 2004. Effects of copper on Ulva flexuosa (Chlorophyta) in vitro. Ecotoxicol. Environ. Saf., 58:117-125.

Boxall, A. B. A.; Comber, S. D.; Conrad, A. U.; Howcroft, J. \& Zaman, N. 2000. Inputs, monitoring and fate modeling of antifouling biocides in UK Estuaries. Mar. Pollut. Bull., 40(11):898-905.

Callow, M. E. \& Callow, J. A. 2002. Marine biofouling: a sticky problem. Biologist 49(1):1-5.

Claise, D. \& Alsieu, C. L. 1993. Copper contaminations as a result of antifouling paints regulation? Mar. Pollut. Bull., 26(7):395-397. 
Carvalho, C. E. \& Lacerda, L. D. 1992. Heavy metals in the Guanabara Bay biota: why such low concentrations? Ci. Cult. J. Ass. Bras. Adv. Sci., 44:184-186.

Correa, J. A.; Gonzáles, P.; Sánchez, P.; Munõz, J. \& Orellana, M. C. 1996. Copper-algae interactions inheritance or adaptation? Environ. Monit. Assessment. 40:41-54.

Donadey, C. \& Besse, G. 1972. Etude histologique, ultrastructurale et experimentale dês caecums digestifs de Porcellio dilatatus et Ligia oceânica (Crustaceae, isopoda). Tethys, 4:145-62.

Gledhill, M.; Nimno, M.; Hill, S. J. \& Brown, T. M. 1997. The toxicity of copper (II) species to marine algae, with particular reference to macroalgae. J.Phycol., 33: 2-11.

Guerra-García, J. M. \& García-Gómez, J. C. 2005. Assessing pollution levels in sediments of a harbor with two opposing entrances. Environmental implications. J. Environ. Mgnt., 77:1-11.

Haritonidis, S. \& Malea, P. 1999. Bioaccumulation of metals by the green alga Ulva rigida from Thermaikos Gulf, Greece. Environ. Pollut., 104:365-372.

Ho, Y. 1987. Metals in 19 intertidal macroalgae in Hong Kong waters. Mar. Pollut. Bull., 18:564-566.

Hopkin, S. P. \& Martin, M. H. 1982. The distribution of zinc, cadmium, lead and copper within woodlouse Oniscus asellus (Crustaceae, Isopoda). Oecologia., 54: 227-32.

IMO - International Maritime Organization. 2001. International Conference on the control of Harmful Antifouling Systems on Ships. London: IMO Headquartes.

Karez, C. S.; Amado Filho, G. M.; Moll, D. M. \& Pfeiffer, W. C. 1994. Concentrações de metais em algas marinhas bentônicas de três regiões do Estado do Rio de Janeiro. An. Acad. bras. Ci., 66 (2):205-211.

Levent, B. A. T.; Ayse, G.; Murat, S.; Mehmet, Ç.; Gamze, G. \& Mehmet, A. 1999. Acute toxicity of zinc, copper and lead to three species of marine organisms from the Sinop Peninsula, Black sea. Turkish. J. Biol., 23:537544.

Löschau, M. \& Krätke, R. 2005. Efficacy and toxicity of selfpolishing biocide-free antifouling paints. Environ. Pollut., 138(2):260-267.

Moore, J. V. \& Ramamurti, S. 1987. Heavy Metals in nearbottom water. Moscow. 285p.

Reed, R. H. \& Moffat, L. 1983. Copper toxicity and copper tolerance in Ulva compressa (L.) Grev. J. expl. mar. Biol. Ecol., 69: 85-103.
Riquelme, C.; Rojas, A.; Flores, V. \& Correa, J. A. 1997. Epiphytic bacteria in a copper-enriched environment in Northern Chile. Mar. Pollut. Bull., 34:816-820.

Ruppert, E. E.; Fox, R. S. \& Barnes, R. D. 2005. Zoologia dos vertebrados: uma abordagem funcional - evolutiva. 7. ed. São Paulo. Rocca, 1.145p.

Schiff, K.; Diehl, D. \& Valkirs, A. O. 2004. Copper emissions from antifouling paint on recreational vessels. Mar. Pollut. Bull., 48: 371-377.

Turner, S. J.; Cummings, V. J.; Hewitt, J. E.; Wilkinson, M. R.; Williamson, R. B. \& Lee, D. J. Changes in epifaunal assemblages in response to marina operations and boating activities. Mar. environ. Res., 43:181-199.

Thouvenin, M.; Peron, J. J.; Charrateurm, C.; Guerin, P.; Langlois, J. Y. \& Vallee-Rehel, K. 2002. A study of the biocide release from antifouling paints. Progr. Org. Coat., 44:75-83.

Valkirs, A. O.; Seligman, P. F.; Haslbeck, E. \& Caso, J. S. 2003. Measurement of copper release rates from antifouling paint under laboratory and in situ conditions: implications for loading estimation to marine water bodies. Mar. Pollut. Bull., 46:763-779.

Warken, J.; Dunn, R. J. K. \& Teasdale, P. R. 2004. Investigation of recreational boats as a source of copper at anchorage sites using time-integrated diffusive gradients in thin film and sediments measurements. Mar. Pollut. Bull., 49:833-843.

Waterman, B. T.; Daehne, B.; Sievers, S.; Dannenberg, R.; Overbeke, J. C.; Klijnstra, J. W. \& Heemken, O. 2005. Bioassays and selected chemical analysis of biocide-free antifouling coatings. Chem., 60:1530-1541.

Wieser, W. 1967. Conquering terra firma: The copper problem from the isopod's point of view. Helgoländer. Wiss. Meeresunter., 15:282-93.

Yenehara, Y.; Yamashita, H.; Kawakamura, C. \& Itoh, K. 2001. A new antifouling paint base don a zinc acrylate copolymerer. Prog. Org. Coat., 42:150-158.

(Manuscript received 09 Juner 2005; revised 06 October 2006; accepted 18 October 2006) 